\title{
The dual amylin and calcitonin receptor agonist KBP-089 and the GLP-1 receptor agonist liraglutide act complimentarily on body weight reduction and metabolic profile
}

Anna Thorsø Larsen ${ }^{\dagger}$, Sofie Gydesen ${ }^{\dagger}$, Nina Sonne, Morten Asser Karsdal and Kim Henriksen ${ }^{*}$

\begin{abstract}
Background: Weight loss therapy is becoming more and more important, and two classes of molecules, namely amylin receptor and GLP-1 receptor agonists, have shown promise in this regard. Interestingly, these molecules have several overlapping pharmacological effects, such as suppression of gastric emptying, reduction of glucagon secretion and weight loss in common; however, they also have distinct effects on prandial insulin secretion. Hence, a combination of these two mechanisms is of significant interest.

Methods: In this study, we investigated the add-on potential of the dual amylin and calcitonin receptor agonist (DACRA) KBP-089 in combination with the GLP-1 receptor agonist liraglutide as obesity treatment in high-fat diet (HFD) fed rats.

Results: Increasing doses of KBP-089 and liraglutide alone and in combination were studied with respect to their effects on body weight, food intake and glucose metabolism during a 9-week intervention study conducted in HFD rats. Further, the gastric emptying rate during an oral glucose tolerance was assessed. Treatment with KBP-089 and liraglutide dose-dependently lowered body weight 15\% (at $2.5 \mu \mathrm{g} / \mathrm{kg} /$ day) and $7 \%$ (at $400 \mu \mathrm{g} / \mathrm{kg} /$ day) in HFD rats, respectively, while the combination resulted in a $21 \%$ body weight reduction, which was mirrored by reduction in fat depot sizes. Gastric emptying and glucose metabolism were improved, primarily by KBP-089, although liraglutide led to a reduction in fasting plasma glucagon.
\end{abstract}

Conclusion: DACRAs complement GLP-1 on food intake, body weight, and glucose tolerance indicating the potential for an add-on therapy.

Keywords: DACRA, GLP-1, Obesity, Glucose tolerance

\footnotetext{
*Correspondence: kh@nordicbio.com

${ }^{\dagger}$ Anna Thorsø Larsen and Sofie Gydesen contributed equally to this work. Nordic Bioscience Biomarkers and Research, Department of Endocrinology, Herlev Hovedgade 207, 2730 Herlev, Denmark
}

(c) The Author(s). 2021 Open Access This article is licensed under a Creative Commons Attribution 4.0 International License, which permits use, sharing, adaptation, distribution and reproduction in any medium or format, as long as you give appropriate credit to the original author(s) and the source, provide a link to the Creative Commons licence, and indicate if changes were made. The images or other third party material in this article are included in the article's Creative Commons licence, unless indicated otherwise in a credit line to the material. If material is not included in the article's Creative Commons licence and your intended use is not permitted by statutory regulation or exceeds the permitted use, you will need to obtain permission directly from the copyright holder. To view a copy of this licence, visit http://creativecommons.org/licenses/by/4.0/. The Creative Commons Public Domain Dedication waiver (http://creativecommons.org/publicdomain/zero/1.0/) applies to the data made available in this article, unless otherwise stated in a credit line to the data. 


\section{Background}

Obesity is an increasing health problem due to modern lifestyle and excessive caloric intake. Multiple complications such as insulin resistance, type 2 diabetes, cardiovascular disease, cancer and non-alcoholic fatty liver disease, among others, are frequently associated with obesity [11, 15, 22]. A sustained weight loss is key in treatment of obesity; however, treatments beside lifestyle intervention are still few. Bariatric surgery is effective, but is only used in severe obesity due to risk of surgical complications [33], therefore alternative therapies with improved efficacy and low risk of side effects are of great interest. Furthermore, a significant weight loss is important in treatment of non-alcoholic fatty liver disease (NAFLD), non-alcoholic steatohepatitis (NASH), and other obesity related morbidities [7, 32].

Multiple GLP-1 agonists are approved for treatment of type 2 diabetes and recently high dose liraglutide was also approved for treatment of obesity, as it promotes sustained weight loss via effects on satiety and appetite [5, 39]. Additionally, liraglutide improves postprandial blood glucose concentration, although still with limitations in terms of tolerability challenges, in particular nausea [3, 8, 23, 27]. There is an increasing focus on combining GLP-1 receptor agonists with additional therapy to obtain greater therapeutic efficacy. In relation to combination therapy, amylin receptor agonism has raised significant interest as a possible candidate, since it has the potential for significant weight reduction and improved glucose control in both preclinical and clinical studies [2, 30, 38]. Additionally, pramlintide has been approved as adjunct to insulin therapy for treatment of type 1 and type 2 diabetes due to its ability to regulate post-prandial glucose levels, reduce body weight, and HbA1c [34, 37, 42]. Dual Amylin and Calcitonin Receptor Agonists (DACRAs) are specifically developed for their ability to activate both the amylin receptor and the calcitonin receptor, as well as their ability to induce typical amylin-induced responses, but with markedly superior potency $[1,12,17,30]$. Importantly, GLP-1 and amylin analogues have several overlapping pharmacological effects including marked reductions in food intake, delay of gastric emptying and inhibition of glucagon secretion, although they act through different sites and mechanisms of action [36].

Previously, combinations of sub-optimal doses of the DACRA KBP-089 and the GLP-1 agonist liraglutide were shown to act complementarily on body weight, food intake and glucose tolerance $[13,14]$, indicating the add-on potential of KBP-089 to liraglutide in obesity treatment. As only sub-optimal doses of KBP-089 and liraglutide have been examined chronically, we here evaluate combination-effects of doses that elicits full response separately $[13,14]$. In this study, we investigated the weight reducing potential of KBP-089 as monotherapy and in combination with the GLP-1 analogue liraglutide in obese high-fat diet fed (HFD) rats.

\section{Methods \\ Peptide therapy}

Synthetic KBP-089 (American Peptide Company, CA, USA) and liraglutide (SynPeptide, Shanghai, China) were dissolved in saline for subcutaneous delivery. The doses chosen for KBP-089 are based on [13, 14] and previous studies with liraglutide $[13,25]$.

\section{Animal experiments}

All animal procedures were performed in accordance with the Animal Welfare Division of the Danish Ministry of Justice under license \#2016-15-0201-00910. 108 male Sprague Dawley (SD) rats (Envigo, Horst, The Netherlands) were obtained at 6 weeks of age and housed as described previously $[13,14]$. Obesity was induced by high fat diet feeding for 10 weeks as described by $[13,14]$.

The rats were allocated into treatment groups according to body weight ( $n=8-10$ rats/treatment group -8 rats in monotherapy groups and 10 rats in combination therapy groups). The rats received doses of KBP-089 (KBP) (0.625, 1.25 and $2.5 \mu \mathrm{g} / \mathrm{kg} \mathrm{sc}$ ), liraglutide (L) (200 and $400 \mu \mathrm{g} / \mathrm{kg}$ sc) and the combinations (KBP $0.625+\mathrm{L} 200 \mu \mathrm{g} / \mathrm{kg}$, KBP $0.625+\mathrm{L} 400 \mu \mathrm{g} / \mathrm{kg}$, KBP $1.25+\mathrm{L} 200 \mu \mathrm{g} / \mathrm{kg}$, KBP $1.25+\mathrm{L}$ $400 \mu \mathrm{g} / \mathrm{kg}$ and KBP $2.5+\mathrm{L} 200 \mu \mathrm{g} / \mathrm{kg}$, KBP $2.5+\mathrm{L} 400 \mu \mathrm{g} /$ $\mathrm{kg}$ ) and vehicle (saline) for 9 weeks. Body weight and food intake were monitored daily in the initial three weeks, then once weekly. Following 4 and 8 weeks of treatment, oral glucose tolerance tests (OGTT) were performed. To assess the treatment effect on gastric emptying, rats received acetaminophen $(40 \mathrm{mg} / \mathrm{kg})$ p.o. gavage $(4 \mathrm{~mL} / \mathrm{kg})$ together with the glucose bolus during OGTT and the appearance of acetaminophen in plasma was measured after $30 \mathrm{~min}$. At study end the rats were euthanized, and epididymal, perirenal and subcutaneous inguinal fat depots were surgically removed and weighed.

\section{Glucose tolerance tests}

OGTTs were performed at 4 and 8 weeks of treatment in rats fasted for $12 \mathrm{~h}$. Rats were pre-dosed with either vehicle or drug at $\mathrm{t}=-30$ and the OGTTs were performed as described previously [9, 12-14].

\section{Biochemical analysis}

Plasma samples for assessment of glucose, insulin and acetaminophen were collected and analysed as described by $[13,14,17]$.

\section{Statistical analysis}

The endpoints were: change in bodyweight, food intake, glucose tolerance and insulin levels. 
All data are presented as mean \pm standard error of the mean (SEM). The statistical analysis of group differences were assessed using one-way ANOVA followed by Tukey's post-hoc test for multiple comparison. Statistical analyses of non-parametric data were conducted using Kruskal Wallis test followed by Dunn's post-hoc test for multiple comparison. Normality of data distribution was determined by D'Agostino and Pearson test normality test. All analyses were performed using GraphPad Prism software (GraphPad Prism, San Diego, CA, USA). A value of $p<0.05$ was considered statistically significant.

\section{Results}

KBP-089 acts complementary with GLP-1 on food intake and body weight loss

To assess whether KBP-089 acts complimentary with GLP-1. KBP-089 and the GLP-1 analogue liraglutide were administered alone or in combination for 9 weeks in HFD rats. 9 weeks of treatment with KBP-089 (0.625, 1.25 and $2.5 \mu \mathrm{g} / \mathrm{kg}$ ) resulted in a dose dependent weight loss (Fig. 1c and supplementary Fig. 1A). Chronic treatment with high concentrations of liraglutide (200 and $400 \mu \mathrm{g} / \mathrm{kg})$ and $\mathrm{KBP}-089(2.5 \mu \mathrm{g} / \mathrm{kg})$ resulted in a 7 and $15 \%$ vehicle-corrected body weight loss, respectively, while the combinations (L $200 \mu \mathrm{g} / \mathrm{kg}+\mathrm{KBP} 2.5 \mu \mathrm{g} / \mathrm{kg}$ and $\mathrm{L} 400 \mu \mathrm{g} / \mathrm{kg}+\mathrm{KBP} 2.5 \mu \mathrm{g} / \mathrm{kg}$ ) resulted in a 17 and $21 \%$ weight reduction, respectively (Fig. $1 \mathrm{c}$ and supplementary Fig. 1A). All treatments significantly reduced food intake in the initial phase of the study (Fig. 1a and supplementary Fig. 1B-C), while only high dose KBP-089 and combination therapy reduced food intake during the entire study (Fig. 1b). Based on food intake and body weight change, food efficiency was calculated. Treatment with the two highest KBP-089 doses (1.25 and $2.5 \mu \mathrm{g} / \mathrm{kg})$ as well as their combinations with liraglutide resulted in a significant reduction in food efficiency compared with

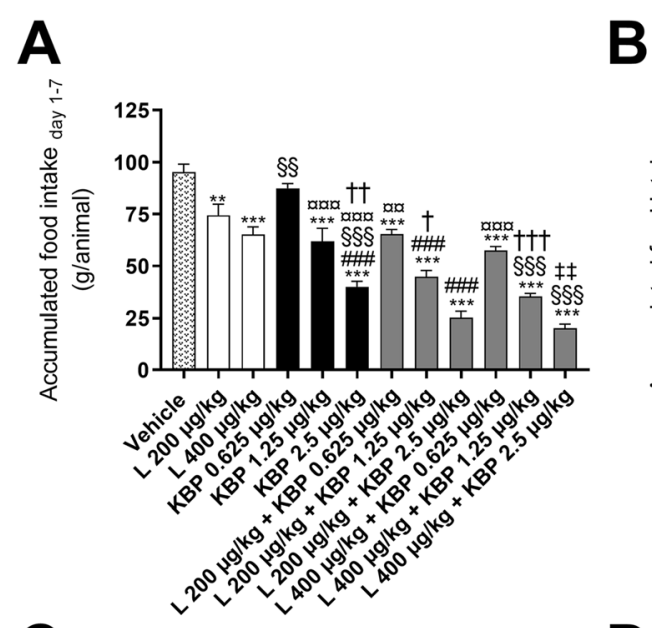

C

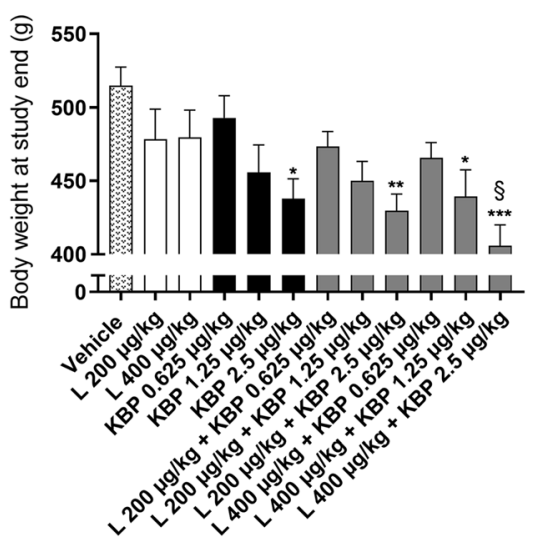

\section{B \\ D}
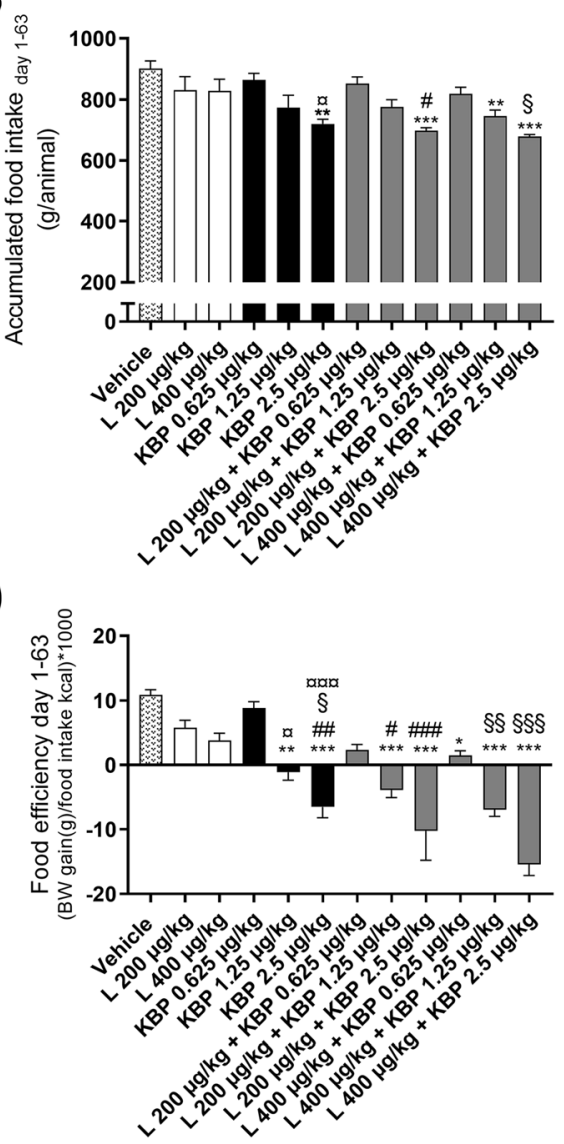

Fig. 1 Accumulated food intake for the initial 7 days (a) and for the entire duration of the study (b). Body weights at study end (c). Calculated food efficiency $(\mathbf{d}) . N=8-10$ rats per group. Statistical analysis between groups were performed as a one-way ANOVA followed by Tukey's posthoc test with the following annotations: ${ }^{*} P<0.05,{ }^{*} P<0.01$, ${ }^{* * *} P<0.001 \mathrm{vs}$. vehicle, $\# P<0.05$, \#\#P<0.01 vs. liraglutide $(200 \mu \mathrm{g} / \mathrm{kg})$, $§ P<0.05$,

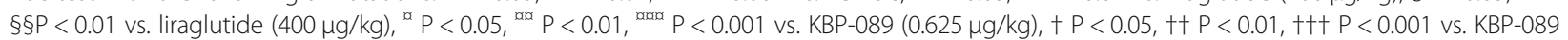
$(1.25 \mu \mathrm{g} / \mathrm{kg})$ and $\neq \neq P<0.01$ vs. KBP-089 $(2.5 \mu \mathrm{g} / \mathrm{kg})$. All data are means $\pm \mathrm{SEM}$ 
vehicle. Additionally, combination treatment was superior to treatment with liraglutide and showed a trend to towards superiority to KBP-089 alone (Fig. 1d).

\section{Treatment with KBP-089 and liraglutide reduces overall adiposity in high fat diet rats}

At study end adipose tissues were isolated and weighed. In conjugation with the significant reduction in body weight, the weight of epididymal white adipose tissues was significantly reduced after treatment with $2.5 \mu \mathrm{g} / \mathrm{kg}$ of KBP-089 and combinations of KBP-089 and liraglutide, whereas only the combination therapy significantly reduced the weights of inguinal and perirenal adipose tissue (Fig. 2a-c).

\section{Treatment with KBP-089 and liraglutide improves oral} glucose tolerance with reduced insulin levels

OGTTs were performed after 4 and 8 weeks of treatment. After 4 weeks of treatment, KBP-089 $(1.25 \mu \mathrm{g} / \mathrm{kg})$ and the combination of high KBP-089 $(2.5 \mu \mathrm{g} / \mathrm{kg})$ and liraglutide $(400 \mu \mathrm{g} / \mathrm{kg})$ had decreased blood glucose levels, though only the combination significantly (Fig. 3a and supplementary Fig. 2A). During the OGTT after 8 weeks of treatment (Fig. 3c and supplementary Fig. 2C), the two combination groups (L $200 \mu \mathrm{g} / \mathrm{kg}+\mathrm{KBP} 2.5 \mu \mathrm{g}$ / $\mathrm{kg}$ and $\mathrm{L} 400 \mu \mathrm{g} / \mathrm{kg}+\mathrm{KBP} 2.5 \mu \mathrm{g} / \mathrm{kg}$ ) were able to significantly improve oral glucose tolerance considering the iAUC (Fig. 3c). After both short and long-term treatment ( 4 and 8 weeks) insulin levels were reduced in rats treated with KBP-089 (1.25 and $2.5 \mu \mathrm{g} / \mathrm{kg})$ while unchanged in rats treated with liraglutide $(200$ and $400 \mu \mathrm{g} /$ $\mathrm{kg}$ ) compared to vehicle, resulting in significantly different iAUC values in KBP-089 and liraglutide treated rats
(Fig. 3b,d). All combinations of the two treatments resulted in insulin levels in the same range as the KBP-089 treated rats, being significantly lower compared to vehicle. In addition, the combination of combination groups receiving the highest dose of KBP-089 (L $200 \mu \mathrm{g} /$ $\mathrm{kg}+\mathrm{KBP} 2.5 \mu \mathrm{g} / \mathrm{kg}$ and $\mathrm{L} 400 \mu \mathrm{g} / \mathrm{kg}+\mathrm{KBP} 2.5 \mu \mathrm{g} / \mathrm{kg}$ ) resulted in significantly lower insulin levels compared to groups treated with liraglutide alone (Fig. 3b,d and supplementary Fig. 2B,D).

High dose Liraglutide, KBP-089 and the combination reduced fasting plasma glucagon levels

Fasting plasma glucagon levels and glucagon levels during OGTT were assessed after 8 weeks of treatment. High dose liraglutide (L $400 \mu \mathrm{g} / \mathrm{kg}$ ), KBP-089 (1.25 and $2.5 \mu \mathrm{g} / \mathrm{kg}$ ) and the combination of slightly reduced fasted plasma glucagon levels compared to vehicle (Fig. 4a). Plasma glucagon levels during OGTT did not differ significantly between treatment (Fig. 4b).

\section{KBP-089 in combination with liraglutide delay gastric emptying rate}

Gastric emptying was assessed in the treatment groups receiving the highest doses of KBP-089, high dose liraglutide and the combination of the two. The rate of gastric emptying during OGTT was assessed after 4 and 8 weeks of treatment (Fig. 5a,b). After both 4 and 8 weeks of treatment administration of KBP-089 $(2.5 \mu \mathrm{g} / \mathrm{kg})$ resulted in a significant reduction of gastric emptying rate $30 \mathrm{~min}$ after acetaminophen administration, while liraglutide (L $400 \mu \mathrm{g} / \mathrm{kg}$ ) had no pronounced effect on gastric emptying (Fig. 5a,b). After 4 weeks of treatment liraglutide reduced gastric emptying by approximately $10 \%$ compared

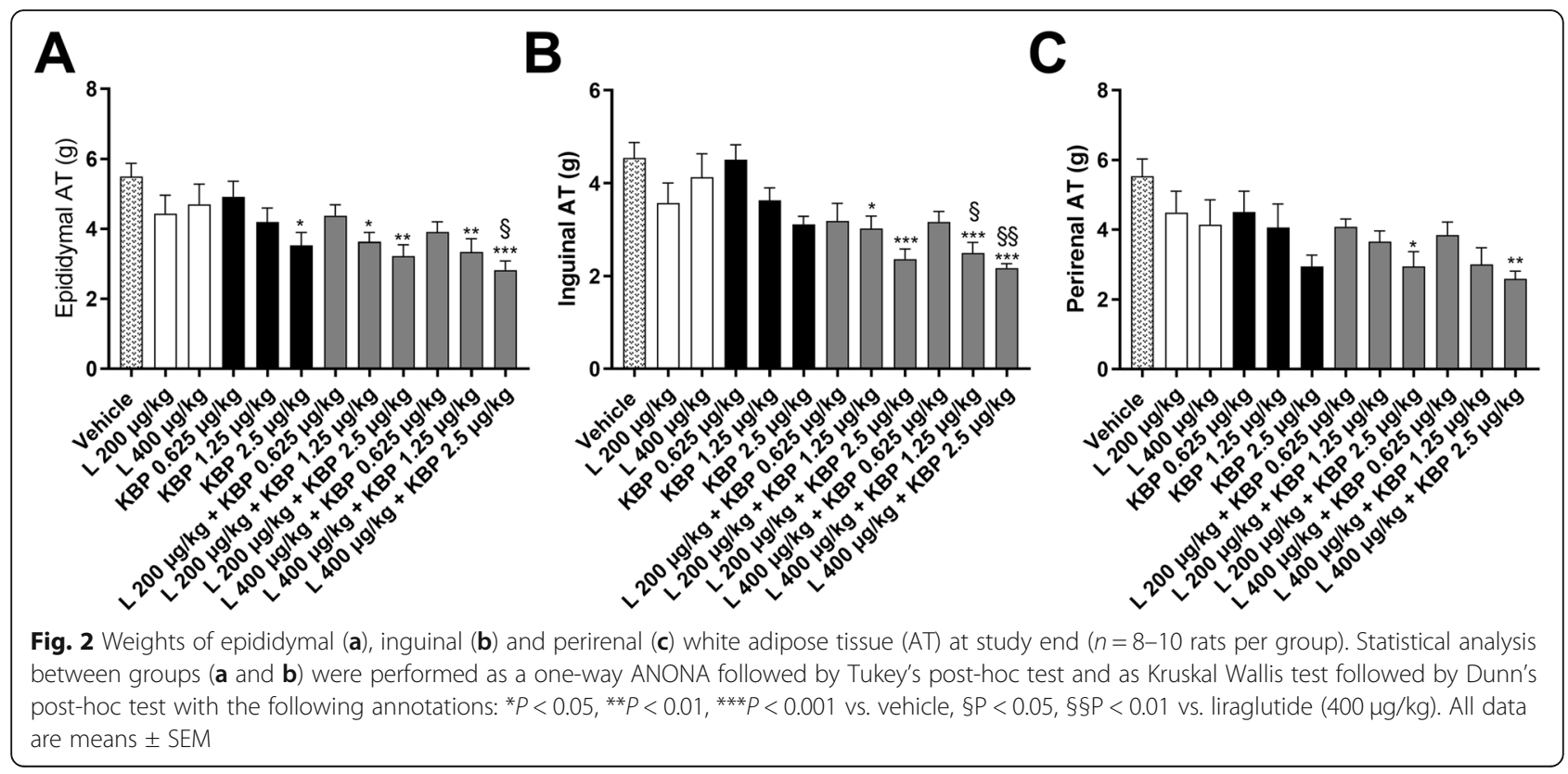




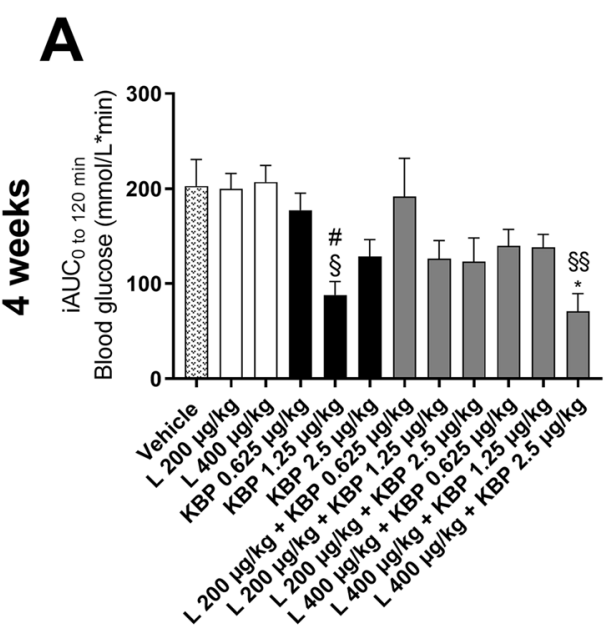

B
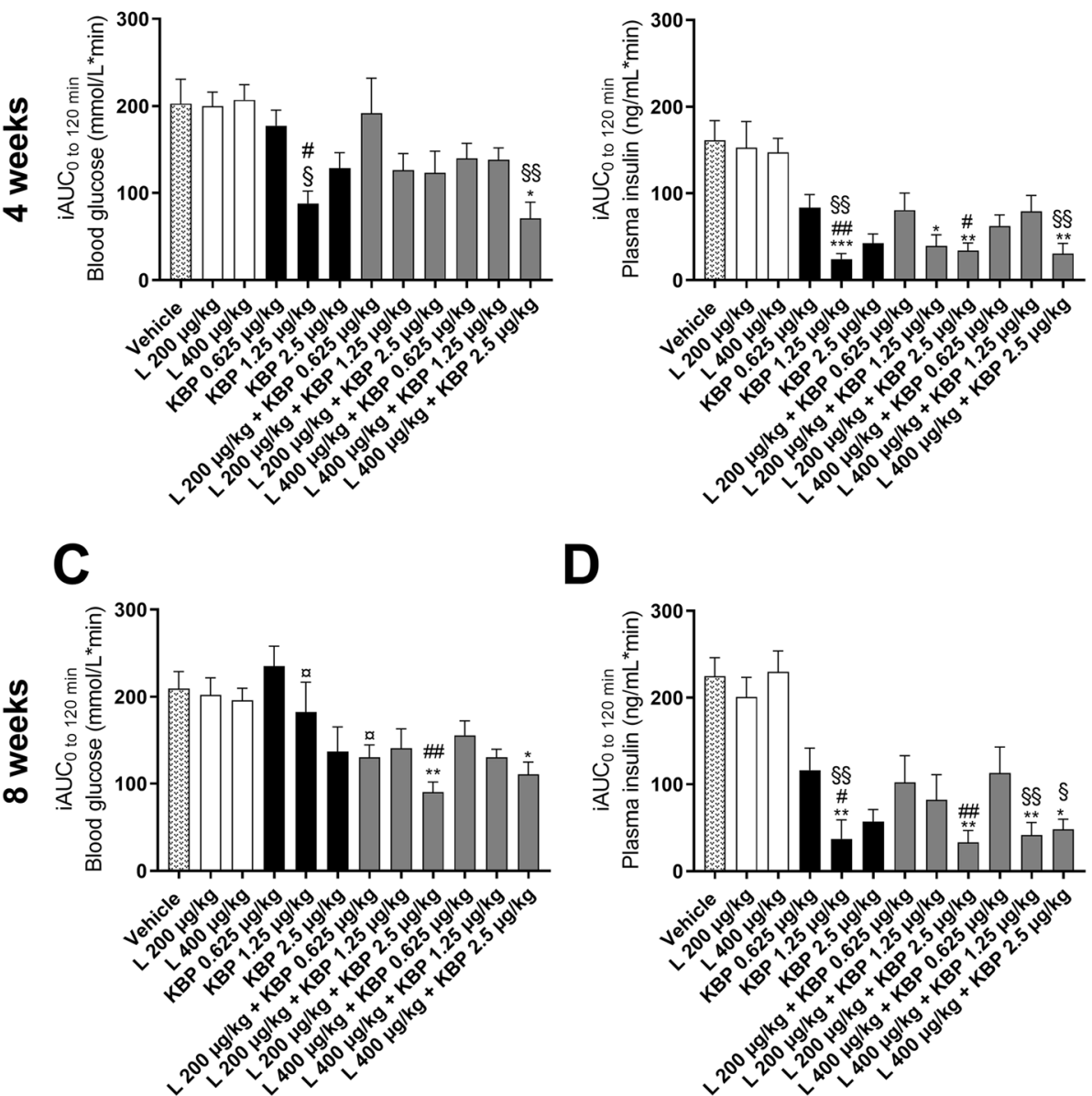

D

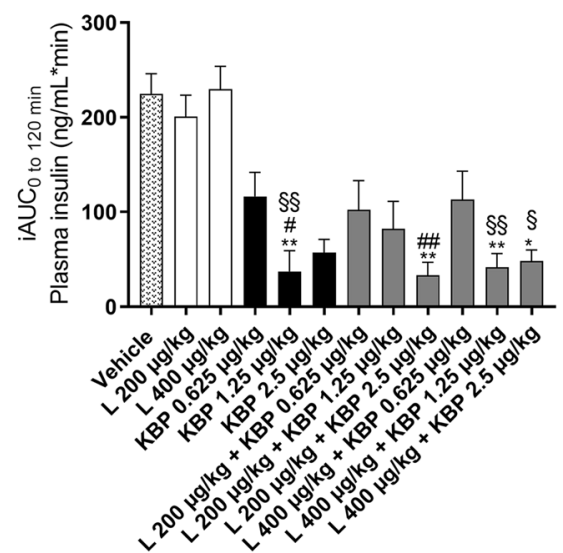

Fig. 3 Oral glucose tolerance test (OGTT) after 4 and 8 weeks of treatment. The incremental area under the curve (iAUC) shown for blood glucose (a and $\mathbf{c}$ ) and plasma insulin (b and $\mathbf{d}$ ) during OGTT after 4 and 8 weeks, respectively. $n=8-10$ rats per group. Statistical analysis between groups were performed as a one-way ANONA followed by Tukey's post-hoc test (c) and as Kruskal Wallis test followed by Dunn's post-hoc test (a, b, d) with the following annotations: ${ }^{*} P<0.05,{ }^{* *} P<0.01,{ }^{* * *} P<0.001 \mathrm{vs}$. vehicle, $\# P<0.05, \# \# P<0.01$ vs. liraglutide $(200 \mu \mathrm{g} / \mathrm{kg}), \S P<0.05, \S \S P<0.01 \mathrm{vs}$. liraglutide $(400 \mu \mathrm{g} / \mathrm{kg}),{ }^{a} P<0.05$ vs. KBP-089 $(0.625 \mu \mathrm{g} / \mathrm{kg})$. All data are means \pm SEM

to vehicle (Fig. 5a), while liraglutide increased gastric emptying by approximately $18 \%$ compared to vehicle after 8 weeks of treatment (Fig. 5b). Additionally, the combination of high dose KBP-089 and liraglutide (L $400 \mu \mathrm{g} / \mathrm{kg}+$ KBP $2.5 \mu \mathrm{g} / \mathrm{kg}$ ) significantly delayed gastric emptying, but equally to KBP-089 treatment alone. This effect on gastric emptying rate was unchanged from 4 (Fig. 5a) to 8 (Fig. 5b) weeks of treatment.

\section{Discussion}

As there is a continuous need for increased potency on weight loss, we investigated the pharmacological potential of combination therapy using the highly potent DACRA KBP-089 and the GLP-1 analog liraglutide for obesity.

In this study, we found a significant effect on appetite suppression and body weight loss when combining the two peptides over a period of nine weeks, an effect superior to either monotherapy alone. Importantly, this also manifested in reduction in food efficiency and overall adiposity. Generally, KBP-089 was superior to liraglutide therapy, and the effects on body weight and food intake dose dependently followed KBP-089 concentrations when combing the two therapies. This suggests that KBP-089 is responsible for the majority of the efficacy of the combination therapy in this study. These findings correspond well with earlier observations using lower doses of the two peptides [13], and demonstrate an additive effect. Previous studies of KBP-089 using pair-feeding have demonstrated a weight loss beyond what is obtained through the reduction of appetite, and have clearly indicated that this effect likely entails increased energy expenditure, or at least a maintenance of energy expenditure, despite the reduction of food intake, 

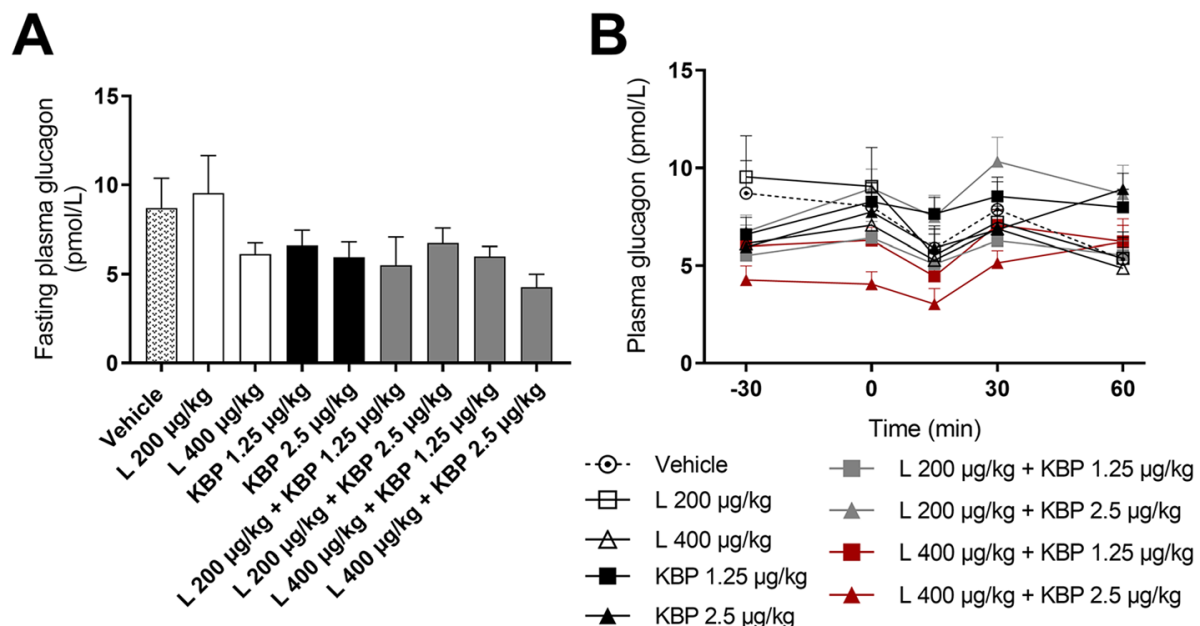

Fig. 4 Fasting plasma glucagon levels (a) and plasma glucagon levels during OGTT after 8 weeks of treatment (b). $n=8-10$ rats per group. Statistical analysis between groups were performed as a one-way ANONA followed by Tukey's post-hoc test. All data are means \pm SEM

a parameter known to reduce energy expenditure [12, $17,29,43]$.

In terms of glucoregulatory actions both amylin receptor agonism [31, 34, 37] and GLP-1R agonism [24, 39, 41] have shown potential. However, the glucose-lowering effect of GLP-1 receptor agonists involves increased post-prandial insulin secretion [26, 40]. During OGTT, both short and long-term treatment with KBP-089 improved glucose tolerance in accordance with previous studies performed with KBP-089 [13, 14]. Interestingly, the effect on blood glucose during OGTT was especially pronounced in combination therapy groups, particularly after eight weeks of treatment, supporting that the peptides act though complimentary pathways, and possibly that the combination leads to increased durability of the glucoregulatory effects compared to stand-alone treatment, consistent with the study by [28]. Importantly, along with improved glucose clearance, significantly lower insulin levels during OGTT were observed in KBP-089 (1.25 and $2.5 \mu \mathrm{g} / \mathrm{kg})$ and combination therapy groups, indicating improved insulin sensitivity. It is likely that the majority of these effects is explained by the massive weight loss; however, DACRAs are known to directly suppress insulin secretion in an IVGTT, as well as directly on the pancreatic islets [1, 17], confirming weight independent effects. Secondly, studies applying pair-fed and pair-weighed controls, as well as studies in ZDF rats, which are insensitive to amylin receptor mediated weight loss [6], have documented glucose regulatory capacities beyond what is observed with weight loss $[12,17]$.
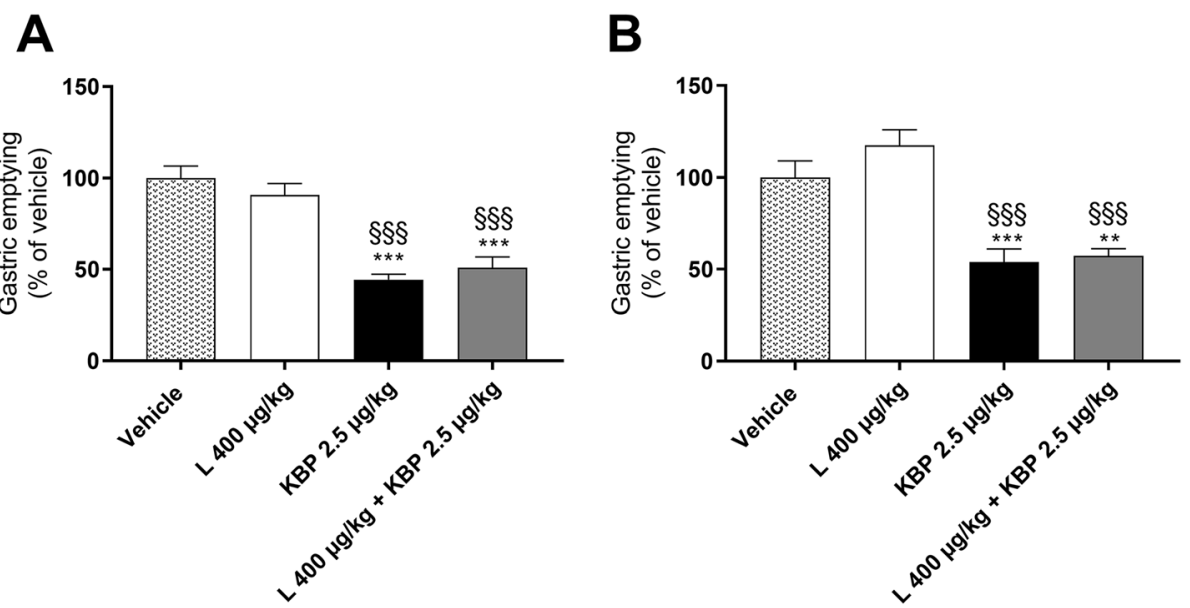

Fig. 5 Gastric emptying after 4 (a) and 8 (b) weeks of treatment. Gastric emptying was estimated by the appearance of acetaminophen in plasma 30 min post dosing and calculated as \% change relative vehicle. Statistical analysis between groups were performed as a one-way ANONA followed by Tukey's post-hoc test with the following annotations: ${ }^{* *} P<0.01,{ }^{* * *} P<0.001$ vs. vehicle and $\S \S \S P<0.001 \mathrm{vs}$. liraglutide $(400 \mu \mathrm{gg} / \mathrm{kg})$. All data are means \pm SEM 
This together with the significant weight loss suggest potential not only as anti-obesity therapy, but also in treatment of obesity related co-morbidities such as type 2 diabetes and NASH [11, 22, 32]. Surprisingly, liraglutide did not increase plasma insulin as expected for a GLP-1 receptor agonist. Other studies in obese rats found similar lack of liraglutide induced increase in plasma insulin during OGTT $[13,35]$, suggesting that the lack of effect observed here might be explained by the animal model that is non-diabetic. Plasma glucagon levels were assessed after 8 weeks of treatment. All treatments, except liraglutide $(200 \mu \mathrm{g} / \mathrm{kg})$, tended towards a lowering of fasting plasma glucagon levels compared to vehicle. Though, all treatment groups had nearly constant glucagon levels during OGTT and no significant differences between groups were observed. This suggests that the HFD rat model does not show inappropriate elevated glucagon levels as seen in diabetic conditions and might explain why there is no clear effect of the therapies post glucose challenge.

GLP-1 and amylin analogues are both known to delay gastric emptying [36], hence gastric emptying rates were assessed. In accordance with earlier studies using DACR As [16, 17], KBP-089 $(2.5 \mu \mathrm{g} / \mathrm{kg})$ markedly reduced gastric emptying after both short- and long-term treatment. A similar effect was observed in the group receiving high-dose combination therapy. Perhaps surprisingly, liraglutide alone only had minor effect on gastric emptying, even trending towards increasing vehicle-corrected gastric emptying after 8 weeks of treatment. Several clinical studies have shown that chronic treatment with liraglutide delays gastric emptying $[10,19,39]$. However, in a pre-clinical setting the ability of liraglutide to reduce gastric emptying markedly diminished within 14 days of treatment, explaining the lack of effect observed here [21]. The inhibited gastric emptying can positively affect postprandial blood glucose levels by delaying entry of glucose into circulation, a central factor in diabetes treatment. From a mechanistic point-of-view, a series of studies have looked into co-administration of either amylin or the DACRA salmon calcitonin (SCT) in combination with incretin-based therapies $[4,12,28]$. These studies have highlighted that both amylin and GLP-1 activate receptors in the same areas of the hind brain, i.e. the dorsal-vagal-complex (DVC), which contains the area postrema and the nucleus tractus solitarius [28]. These studies showed a combined effect of SCT and liraglutide on c-fos activation in the DVC, consistent with a combined suppression of food intake and gastric emptying [12, 28]. Furthermore, earlier work indicated that this effect may entail a local upregulation of brain IL-6 in the hypothalamus, by both amylin and GLP-1 [20]. Hence, while the complete picture of how the combination works is still unclear, there is evidence supporting that it entails common signaling pathways.
Importantly, there are some limitations to the study presented here. The weight lowering and glucoregulatory actions of both the mono- and the combination therapies are limited by model, as the HFD rat model does not develop diabetes, but only modest insulin resistance due to obesity. Furthermore, despite previous studies in diabetic model systems showing suppression of hyperglucagonemia [18], we only detected trends towards suppression of glucagon levels, most likely due to the model system only representing a mild disease. This is also seen for the weight loss, where the differences are rather small in the combination therapy arms of the study, as these seem to have reached maximal weight loss, albeit the lack of a lean control group confounds this conclusion. All in all, further studies in a diabetic model would be of importance.

In conclusion, KBP-089 acts complementary with the GLP-1 analogue, liraglutide, on food consumption, weight loss and glucose tolerance, indicating the potential for an add-on therapy causing additional improvement in metabolic profile.

\section{Supplementary Information}

The online version contains supplementary material available at https://doi. org/10.1186/s12902-020-00678-2.

Additional file 1.

Additional file 2.

Abbreviations

ANOVA: Analysis of Variance; DACRA: Dual Amylin and Calcitonin Receptor Agonists; ELISA: Enzyme-linked immunosorbent assay; GLP-1: Glucagon-like peptide 1; HFD: High Fat Diet; (i)AUC: (incremental) Area Under the Curve; OGTT: Oral Glucose Tolerance Test; SEM: Standard error of the mean

Acknowledgements

Not applicable.

Authors' contributions

Participated in the research design: SGY, KH, MK, Conducted experiments: ATL, SGY, Performed data analysis: ATL, SGY, All authors have read and approved the final manuscript.

\section{Funding}

Funding by the Danish Research Foundation (Den Danske Forskningsfond) was granted to ATL and SGY (Grant numbers N/A).

Availability of data and materials

The datasets used and/or analyzed during the current study are available from the corresponding author on reasonable request.

\section{Ethics approval}

All studies were approved by the Danish Animal Inspectorate (approval number: 2016-15-0201-00910).

Consent for publication

Not applicable.

\section{Competing interests}

$\mathrm{MK}$ and $\mathrm{KH}$ own stocks in Nordic Bioscience. MK and $\mathrm{KH}$ hold patents on KBPs. All authors are employees of Nordic Bioscience. 
Received: 2 July 2020 Accepted: 30 December 2020 Published online: 07 January 2021

\section{References}

1. Andreassen KV, Feigh M, Hjuler ST, Gydesen S, Henriksen JE, Beck-Nielsen H, Christiansen C, M a K, Henriksen K. A novel oral dual amylin and calcitonin receptor agonist (KBP-042) exerts antiobesity and antidiabetic effects in rats. Am J Physiol Endocrinol Metab. 2014;307:E24-33.

2. Aronne L, Fujioka K, Aroda V, Chen K, Halseth A, Kesty NC, Burns C, Lush $\mathrm{CW}$, Weyer $\mathrm{C}$. Progressive reduction in body weight after treatment with the amylin analog pramlintide in obese subjects: A phase 2, randomized, placebo-controlled, dose-escalation study. J Clin Endocrinol Metab. 2007;92: 2977-83.

3. Astrup A, Carraro R, Finer N, Harper A, Kunesova M, MEJ L, Niskanen L, Rasmussen MF, Rissanen A, Rossner S, Savolainen MJ, Van Gaal L. Safety, tolerability and sustained weight loss over 2 years with the once-daily human GLP-1 analog, liraglutide. Int J Obes (Lond). 2012;36: 843-54 England.

4. Bello NT, Kemm MH, Ofeldt EM, Moran TH. Dose combinations of exendin-4 and salmon calcitonin produce additive and synergistic reductions in food intake in nonhuman primates. Am J Physiol Integr Comp Physiol. 2010;299: R945-52.

5. Crane J, McGowan B. The GLP-1 agonist, liraglutide, as a pharmacotherapy for obesity. Ther Adv Chronic Dis. 2016;7:92-107.

6. Duffy S, Lutz TA, Boyle CN. Rodent models of leptin receptor deficiency are less sensitive to amylin. Am J Physiol Regul Integr Comp Physiol. 2018;315: R856-65.

7. Cusi K. Role of Insulin Resistance and Lipotoxicity in Non-Alcoholic Steatohepatitis. Clin Liver Dis. 2009;13:545-63.

8. Davies MJ, Bergenstal R, Bode B, Kushner RF, Lewin A, Skjoth TV, Andreasen $\mathrm{AH}$, Jensen CB, DeFronzo RA. Efficacy of Liraglutide for Weight Loss Among Patients With Type 2 Diabetes: The SCALE Diabetes Randomized Clinical Trial. JAMA. 2015;314:687-99 United States.

9. Feigh M, Henriksen K, Andreassen KV, Hansen C, Henriksen JE, Christiansen C, Karsdal MA. A novel oral form of salmon calcitonin improves glucose homeostasis and reduces body weight in diet-induced obese rats. Diabetes, Obes Metab. 2011;13:911-20.

10. Flint A, Kapitza C, Hindsberger C, Zdravkovic M. The once-daily human Glucagon-Like Peptide-1 (GLP-1) analog liraglutide improves postprandial glucose levels in type 2 diabetes patients. Adv Ther. 2011;28:213-26.

11. Guh DP, Zhang W, Bansback N, Amarsi Z, Birmingham L, Anis AH. The incidence of co-morbidities related to obesity and overweight : A systematic review and meta-analysis. BMC Public Health. 2009;9:1-20.

12. Gydesen S, Andreassen KV, Hjuler ST, Christensen JM, Karsdal MA, Henriksen K. KBP-088, a novel DACRA with prolonged receptor activation, is superior to davalintide in terms of efficacy on body weight. Am J Physiol Endocrinol Metab ajpendo. 2016;00514:2015.

13. Gydesen S, Andreassen KV, Hjuler ST, Hellgren LI, Karsdal MA, Henriksen K. Optimization of Tolerability and Efficacy of Dual Amylin and Calcitonin Receptor Agonist, KBP-089, through Dose Escalation and Combination with a GLP-1 Analogue. Am J Physiol - Endocrinol Metab ajpendo. 2017a;00419:2016.

14. Gydesen S, Hjuler ST, Freving Z, Andreassen KV, Sonne N, Hellgren LI, Karsdal MA, Henriksen K. A novel Dual Amylin and Calcitonin Recepto Agonist (DACRA), KBP-089, induces weight loss through a reduction in fat, but not lean mass, while improving food preference. Br J Pharmacol. 2017b; 174:591-602.

15. Haslam DW, James WPT. Obesity. Lancet (London, England). 2005;366:1197209 England.

16. Hjuler ST, Andreassen KV, Gydesen S, Karsdal MA, Henriksen K. KBP-042 improves bodyweight and glucose homeostasis with indices of increased insulin sensitivity irrespective of route of administration. Eur J Pharmacol. 2015;762:229-38

17. Hjuler ST, Gydesen S, Andreassen KV, Lund S, Pedersen K, Hellgren LI, Karsdal MA, Henriksen K. The Dual Amylin- and Calcitonin-Receptor Agonist KBP-042 Increases Insulin Sensitivity and Induces Weight Loss in Rats with Obesity. Obesity. 2016;24:1712-22.

18. Hjuler ST, Gydesen S, Andreassen KV, Karsdal MA, Henriksen K. The Dual Amylin- and Calcitonin Receptor Agonist KBP-042 Works as Adjunct to Metformin on Fasting Hyperglycemia and $\mathrm{HbA1}$ in a Rat Model of Type 2 Diabetes. J Pharmacol Exp Ther. 2017;362:24-30.
19. Horowitz M, Flint A, Jones KL, Hindsberger C, Rasmussen MF, Kapitza C, Doran S, Jax T, Zdravkovic M, Chapman IM. Effect of the once-daily human GLP-1 analogue liraglutide on appetite, energy intake, energy expenditure and gastric emptying in type 2 diabetes. Diabetes Res Clin Pract. 2012;97: 258-66 Elsevier Ireland Ltd.

20. Jansson JO, Palsdottir V. Brain IL-6 - Where amylin and GLP-1 antiobesity signaling congregate. Diabetes. 2015;64:1498-9.

21. Jelsing J, Vrang N, Hansen G, Raun K, Tang-Christensen M, Bjerre Knudsen L. Liraglutide: Short-lived effect on gastric emptying-long lasting effects on body weight. Diabetes, Obes Metab. 2012;14:531-8.

22. Kahn SE, Hull RL, Utzschneider KM. Mechanisms linking obesity to insulin resistance and type 2 diabetes. Nature. 2006:444:840-6.

23. Kanoski SE, Rupprecht LE, Fortin SM, De Jonghe BC, Hayes MR. The role of nausea in food intake and body weight suppression by peripheral GLP-1 receptor agonists, exendin-4 and liraglutide. Neuropharmacology. 2012;62: 1916-27 Elsevier Ltd

24. Klein DJ, Battelino T, Chatterjee DJ, Jacobsen LV, Hale PM, Arslanian S. Liraglutide's Safety, Tolerability, Pharmacokinetics, and Pharmacodynamics in Pediatric Type 2 Diabetes: A Randomized, Double-Blind, Placebo-Controlled Trial. Diabetes Technol Ther. 2014;16:679-87.

25. Knudsen LB. Liraglutide: The therapeutic promise from animal models. Int J Clin Pract. 2010;64:4-11 Blackwell Publishing Ltd.

26. Ladenheim EE. Liraglutide and obesity: A review of the data so far. Drug Des Devel Ther. 2015;9:1867-75.

27. Lean MEJ, Carraro R, Finer N, Hartvig H, Lindegaard ML, Rössner S, Van Gaal $L$, Astrup A. Tolerability of nausea and vomiting and associations with weight loss in a randomized trial of liraglutide in obese, non-diabetic adults. Int J Obes. 2014:38:689-97.

28. Liberini CG, Koch-Laskowski K, Shaulson E, McGrath LE, Lipsky RK, Lhamo R, Ghidewon M, Ling T, Stein LM, Hayes MR. Combined Amylin/GLP-1 pharmacotherapy to promote and sustain long-lasting weight loss. Sci Rep. 2019;9:8447.

29. Mack C, Wilson J, Athanacio J, Reynolds J, Laugero K, Guss S, Vu C, Roth J, Parkes D. Pharmacological actions of the peptide hormone amylin in the long-term regulation of food intake, food preference, and body weight. Am J Physiol Regul Integr Comp Physiol. 2007;293:R1855-63.

30. Mack CM, Soares CJ, Wilson JK, Athanacio JR, Turek VF, Trevaskis JL, Roth JD, Smith PA, Gedulin B, Jodka CM, Roland BL, Adams SH, Lwin A, Herich J, Laugero KD, Vu C, Pittner R, Jr JRP. Davalintide ( AC2307 ), a novel amylinmimetic peptide : enhanced pharmacological properties over native amylin to reduce food intake and body weight; 2010. p. 385-95.

31. Mack CM, Smith PA, Athanacio JR, Xu K, Wilson JK, Reynolds JM, Jodka CM, Lu MGW, Parkes D. Glucoregulatory effects and prolonged duration of action of davalintide: a novel amylinomimetic peptide. Diabetes, Obesity Metab. 2011:13:1105-13.

32. Milić S, Lulić D, Štimac D. Non-alcoholic fatty liver disease and obesity: Biochemical metabolic and clinical presentations. World J Gastroenterol. 2014:20:9330-7.

33. Pories WJ. Bariatric surgery: Risks and rewards. J Clin Endocrinol Metab. 2008;93:89-96.

34. Ratner RE, Dickey R, Fineman M, Maggs DG, Shen L, Strobel SA, Weyer C, Kolterman OG. Amylin replacement with pramlintide as an adjunct to insulin therapy improves long-term glycaemic and weight control in Type 1 diabetes mellitus : a 1-year, randomized controlled trial. Diabet Med. 2004;21:1204-12.

35. Raun K, Von Voss P, Gotfredsen CF, Golozoubova V, Rolin B, Knudsen LB. Liraglutide, a long-acting glucagon-like peptide-1 analog, reduces body weight and food intake in obese candy-fed rats, whereas a dipeptidyl peptidase-IV inhibitor, vildagliptin, does not. Diabetes. 2007;56:8-15.

36. Roth JD, Erickson MR, Chen S, Parkes DG. GLP-1R and amylin agonism in metabolic disease: Complementary mechanisms and future opportunities. Br J Pharmacol. 2012;166:121-36.

37. Ryan G, Briscoe TA, Jobe L. Review of pramlintide as adjunctive therapy in treatment of type 1 and type 2 diabetes. Drug Des Devel Ther. 2008;2:203-14.

38. Smith SR, Aronne LJ, Burns CM, Kesty NC, Halseth AE, Weyer C. Sustained weight loss following 12-month pramlintide treatment as an adjunct to lifestyle intervention in obesity. Diabetes Care. 2008;31:1816-23.

39. Van Can J, Sloth B, Jensen CB, Flint A, Blaak EE, Saris WHM. Effects of the once-daily GLP-1 analog liraglutide on gastric emptying, glycemic parameters, appetite and energy metabolism in obese, non-diabetic adults. Int J Obes. 2014;38:784-93. 
40. Vilsbøll T, Brock B, Perrild H, Levin K, Lervang H, Kølendorf $K$, Krarup T, Schmitz O, Zdravkovic M, Madsbad S. Original Article: Treatment Liraglutide, a once-daily human GLP-1 analogue, improves pancreatic B-cell function and arginine-stimulated insulin secretion during hyperglycaemia in patients with Type 2 diabetes mellitus. Diabet Med. 2008;25:152-6.

41. Vilsbøøll T, Zdravkovic M, Le-Thi T, Krarup T, Schmitz O, Courreges J-P, Verhoeven R, Buganova I, Madsbad S. Liraglutide, a Long-Acting Human Glucagon-Like Peptide-1 Analog, Given as Monotherapy Significantly Improves Glycemic Control and Lowers Body Weight Without Risk of Hypoglycemia in Patients With Type 2 Diabetes. Diabetes Care. 2007;30: 1608-10.

42. Weyer C, Maggs DG, Young AA, Kolterman OG. Amylin replacement with pramlintide as an adjunct to insulin therapy in type 1 and type 2 diabetes mellitus: A physiological approach toward improved metabolic control. Curr Pharm Des. 2001;7:1353-73.

43. Wielinga PY, Lowenstein C, Muff S, Munz M, Woods SC, Lutz TA. Central amylin acts as an adiposity signal to control body weight and energy expenditure. Physiol Behav. 2010;101:45-52.

\section{Publisher's Note}

Springer Nature remains neutral with regard to jurisdictional claims in published maps and institutional affiliations.

Ready to submit your research? Choose BMC and benefit from:

- fast, convenient online submission

- thorough peer review by experienced researchers in your field

- rapid publication on acceptance

- support for research data, including large and complex data types

- gold Open Access which fosters wider collaboration and increased citations

- maximum visibility for your research: over $100 \mathrm{M}$ website views per year

At BMC, research is always in progress.

Learn more biomedcentral.com/submissions 